Article

\title{
Soil Aggregation and Organic Carbon Dynamics in Poplar Plantations
}

\author{
Zhiwei Ge ${ }^{1}$, Shuiyuan Fang ${ }^{2}$, Han Y.H. Chen ${ }^{3}{ }^{(\mathbb{D}}$, Rongwei Zhu ${ }^{1}$, Sili Peng ${ }^{1}$ \\ and Honghua Ruan ${ }^{1, *}$ \\ 1 Co-Innovation Center for Sustainable Forestry in Southern China, College of Biology and the Environment, \\ Nanjing Forestry University, Nanjing 210037, China; gezhiwei@njfu.edu.cn (Z.G.); \\ 13770713796@163.com (R.Z.); pengsili@njfu.edu.cn (S.P.) \\ 2 Tongzi County Forestry Bureau of Guizhou, Tongzi 563200, China; shuiyuanfangtz@163.com \\ 3 Faculty of Natural Resources Management, Lakehead University, Thunder Bay, ON P7B 5E1, Canada; \\ hchen1@lakeheadu.ca \\ * Correspondence: hhruan@njfu.edu.cn; Tel.: +86-025-854-27-312
}

Received: 26 June 2018; Accepted: 21 August 2018; Published: 23 August 2018

\begin{abstract}
Soil resident water-stable macroaggregates (diameter $(\varnothing)>0.25 \mathrm{~mm}$ ) play a critical role in organic carbon conservation and fertility. However, limited studies have investigated the direct effects of stand development on soil aggregation and its associated mechanisms. Here, we examined the dynamics of soil organic carbon, water-stable macroaggregates, litterfall production, fine-root $(\varnothing<1 \mathrm{~mm})$ biomass, and soil microbial biomass carbon with stand development in poplar plantations (Populus deltoides L. '35') in Eastern Coastal China, using an age sequence (i.e., five, nine, and 16 years since plantation establishment). We found that the quantity of water-stable macroaggregates and organic carbon content in topsoil (0-10 cm depth) increased significantly with stand age. With increasing stand age, annual aboveground litterfall production did not differ, while fine-root biomass sampled in June, August, and October increased. Further, microbial biomass carbon in the soil increased in June but decreased when sampled in October. Ridge regression analysis revealed that the weighted percentage of small $(0.25 \mathrm{~mm} \leq \varnothing<2 \mathrm{~mm})$ increased with soil microbial biomass carbon, while that of large aggregates $(\varnothing \geq 2 \mathrm{~mm})$ increased with fine-root biomass as well as microbial biomass carbon. Our results reveal that soil microbial biomass carbon plays a critical role in the formation of both small and large aggregates, while fine roots enhance the formation of large aggregates.
\end{abstract}

Keywords: fine-root biomass; stand development; poplar plantation; soil macroaggregates; soil organic carbon

\section{Introduction}

Soil aggregation, a primary determinant of soil fertility and productivity, results from the rearrangement of soil particles, flocculation and cementation, which is facilitated by organic inorganic compounds (particularly long-chain polysaccharides and proteins, ionic bridging, and carbonates) [1-3]. Soil aggregates are formed in varying size classes, which are commonly classified as microaggregates (diameter $(\varnothing) \leq 0.25 \mathrm{~mm}$ ) and macroaggregates $(\varnothing>0.25 \mathrm{~mm})$ [4]. The weight percentage of water-stable macroaggregates (WSM) might serve as indicators of soil quality by virtue of their large surface areas and strong chemical bonds [5,6]. An understanding of how management practices affect soil aggregation is critical to the long-term maintenance of soil productivity, reduction of erosion and conservation of organic matter [7-10]. Stand development following afforestation may improve the physical and chemical properties of damaged and young soils [11,12]. The loss of soil carbon and 
aggregates following deforestation has been frequently documented [13-17]. However, limited studies have investigated the direct effects of stand development following afforestation, on the formation and stability of macroaggregates $[9,18]$.

Under a given site condition, several biotic mechanisms such as plant carbon (C) inputs and microbial activity may be responsible for soil aggregation [19]. Increases in soil organic carbon (SOC) with stand development following afforestation have been attributable to increases in C inputs and enhanced organic matter protection in arid and semi-arid ecosystems [18]. Many factors may potentially determine the formation of WSM, such as mycorrizeal hyphal network, bacteria biomass [20], decomposition of plant residue [21], root systems of trees [22], and understory vegetation $[23,24]$. Recent evidence has revealed that aboveground plant litter input is strongly related to the formation of soil macroaggregates [8,25-27]. The formation of WSM associated with organic matter decomposition products and plant root exudates [28,29] were also reported, as they serve as the source of $C$ for microbial activities, which in turn facilitate the formation of organic and inorganic compounds [30]. The mean diameters and weights of aggregates, as well as root biomass, have been reported to increase following the conversion of pastureland to plantations $[18,31]$. Fine roots may have potent effects on soil aggregation in tree plantations due to their enormous biomass and large interfacial contact area with the soil [32,33]. Dead fine roots contribute strongly to macroaggregate-associated SOC stocks [18]; however, the relative influences of aboveground litterfall and fine roots on soil $\mathrm{C}$ and aggregates remain under debate. Moreover, soil microbes, which are essential drivers for the decomposition of organic matter and the formation of organic and inorganic compounds, may influence the generation of aggregates and soil C [19,30]. Similar to fine roots [34,35], soil microbes are highly seasonally variable [36-38].

Poplar (Populus L. species) is the most cultivated genera, in terms of mean planted area in China, due to its high economic value and role in $C$ sequestration in soils, particularly in saline-alkali coastal areas, as it is salt-tolerant $[39,40]$. A clearer elucidation of soil aggregation and $C$ dynamics of poplar plantations may assist in the development of management policies that are aimed at restoring vast coastal lands with alluvial soils in China. Our objectives were to examine how the WSM and organic C content were altered with stand development, and how they might be linked with plant litterfall, fine-root biomass and soil microbial biomass carbon (SMBC) in poplar plantations of coastal China. We hypothesized that (1) the quantities of WSM and SOC would increase with stand development following afforestation; (2) the quantities of WSM and SOC would be positively associated with plant litterfall, fine-root biomass, and SMBC as higher fresh organic matter inputs with stand development may increase SOC and enhance soil aggregation [2,41]. We sampled the topsoil $(0-10 \mathrm{~cm}$ depth) of poplar plantations using a replicated chronosequence approach in the Eastern coast of China.

\section{Materials and Methods}

\subsection{Study Area and Sites}

The study area was located in the Dongtai Forest Farm, a coastal area of the Yellow Sea in the Northern Jiangsu Province of Eastern China $\left(120^{\circ} 49^{\prime} \mathrm{E}\right.$ and $\left.32^{\circ} 52^{\prime} \mathrm{N}\right)$. The climate alternates between subtropical and warm temperate zones with monsoon influences. The growing season extends from May to October, whereas the dry season spans from November to April. The mean annual rainfall is $1050 \mathrm{~mm}$, with an average temperature of $14.6^{\circ} \mathrm{C}$, and a frost-free period of 220 days [42]. Meanwhile, the average diurnal temperature had a subtle fluctuation, that is, from $28.1^{\circ} \mathrm{C}$ (July), and $27.7^{\circ} \mathrm{C}$ (August) to $24.1^{\circ} \mathrm{C}$ (June) and $21.6^{\circ} \mathrm{C}$ (September). Even in the last month (October) of the growing season, the average daily temperature was $17.6^{\circ} \mathrm{C}$.

The farm was reclaimed from the ocean via the construction of coastal levees, and is currently part of the saline land of silting coastal area (alluvial soil) with an electrical conductivity of $2.68 \pm 0.58 \mathrm{ds} / \mathrm{m}$. The soil may be termed as fluvisols in the taxonomy of the Food and Agriculture Organization of the United Nations (FAO). Once alluvial soils are formed above sea level (five-ten-years), the land 
is typically converted to tree plantations with species such as Populus deltoides L. 'Lux' (Italy-69/55), Populus $\times$ euramericana 'San martino' (Italy-72/58), Populus deltoides L. '35/66', Populus $\times$ euramericana L. 'JP7', Metasequoia glyptostroboides Miki ex Hu, and Ginkgo biloba L.). During the establishment of the tree plantation, shrubs and herbaceous plants were not removed.

\subsection{Sampling Design}

We employed a chronosequence approach to the sample stands that varied in age. Although the use of the chronosequence method has been criticized, as it makes the assumption that sample stands along the temporal sequence have followed the same developmental history [43], given careful site selection and replication, the chronosequence method is well suited for studying stand dynamics over decadal time scales [44]. Given the availability of the stand ages in the study area, we selected five-, nine-, and 16-year-old poplar (Populus deltoides L. '35') plantations with an area of 3.3 ha each. For each age class, we selected three sites that were spatially interspersed, with a distance between sites among all age classes of $>1 \mathrm{~km}$ (Figure 1$)$.

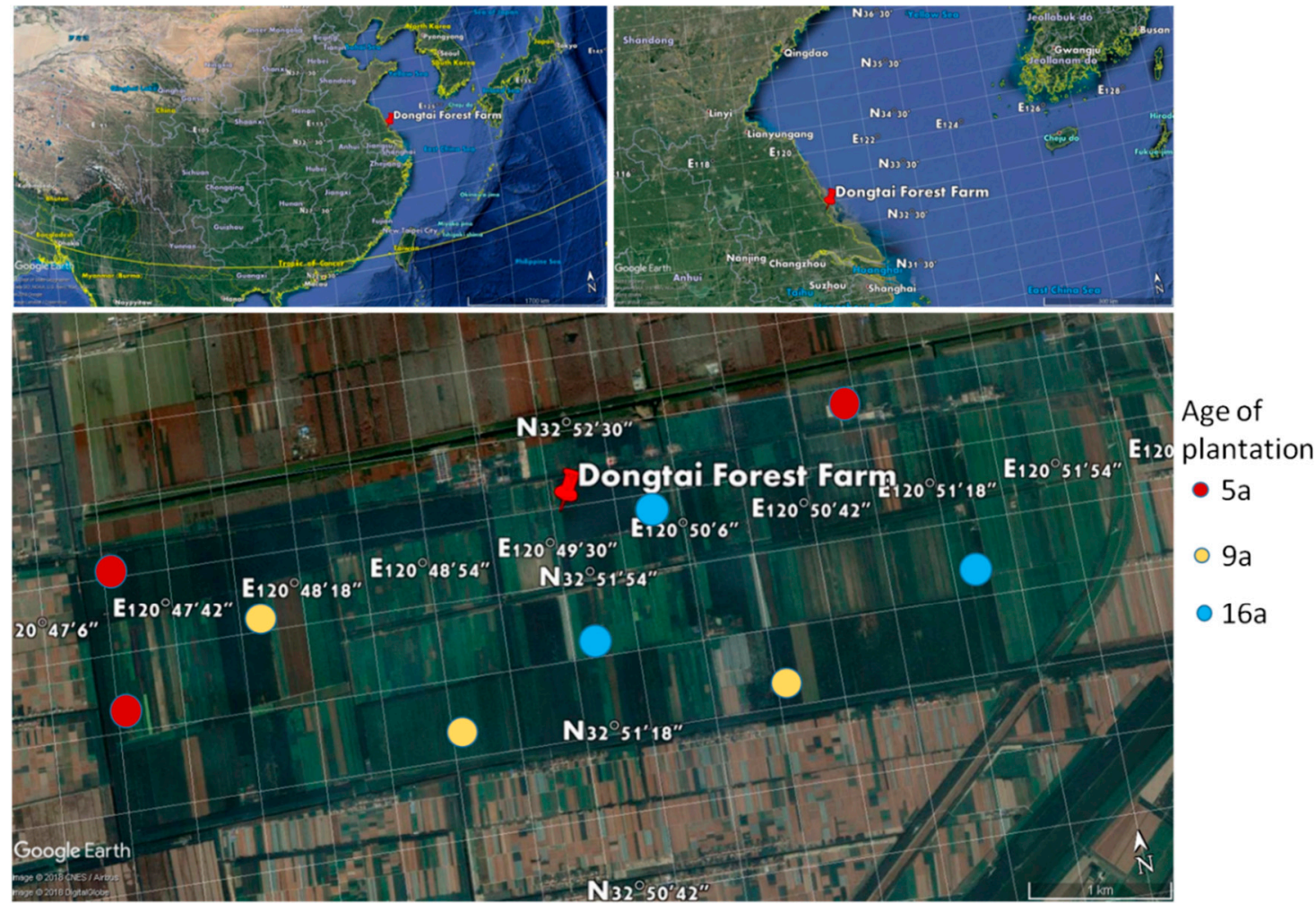

Figure 1. The location of Dongtai Forest Farm and sampling sites.

At each site, a plot $\left(750 \mathrm{~m}^{2}, 25 \mathrm{~m} \times 30 \mathrm{~m}\right)$ was randomly established. The diameter at breast height of all live trees was measured at $1.3 \mathrm{~m}$ above the root collar (Table 1 ). To ensure an inherent similarity between sites, we assessed soil textures following the method described by Cavard et al. [45], and collected the understory biomass in September 2013 via a harvesting method. The understory biomass and soil texture, determined by sieving and sedimentation [46], were similar among stand

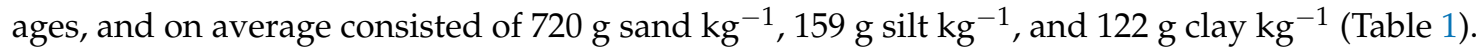


Table 1. Soil properties and stand characteristics in poplar plantations at different ages (mean \pm s.e.m., $n=3)$.

\begin{tabular}{cccc}
\hline Age of Plantation (Years) & $\mathbf{5}$ & $\mathbf{9}$ & $\mathbf{1 6}$ \\
\hline Height $(\mathrm{m})$ & $18.1 \pm 0.8$ & $21.3 \pm 1.7$ & $23.6 \pm 0.4$ \\
Diameter at breast height $(\mathrm{cm})$ & $16.2 \pm 0.5$ & $23.1 \pm 1.2$ & $28.6 \pm 1.7$ \\
Canopy closure $(\%)$ & $43.6 \pm 4.8$ & $53.6 \pm 4.8$ & $75.0 \pm 4.1$ \\
Understory biomass $\left(\mathrm{g} / \mathrm{m}^{2}\right)$ & $101.0 \pm 3.9$ & $97.8 \pm 2.3$ & $98.7 \pm 3.5$ \\
$\mathrm{pH}$ & $8.34 \pm 0.15$ & $8.25 \pm 0.17$ & $8.31 \pm 0.13$ \\
$\mathrm{C} / \mathrm{N}$ & $13.2 \pm 0.16$ & $13.5 \pm 0.23$ & $17.3 \pm 0.20$ \\
Sand $(\mathrm{g} / \mathrm{kg})$ & $719.7 \pm 17.2$ & $719.0 \pm 17.5$ & $722.3 \pm 23.5$ \\
Silt $(\mathrm{g} / \mathrm{kg})$ & $162.0 \pm 12.8$ & $153.0 \pm 4.5$ & $161.3 \pm 6.3$ \\
Clay $(\mathrm{g} / \mathrm{kg})$ & $130.2 \pm 0.8$ & $119.8 \pm 2.2$ & $116.5 \pm 1.7$ \\
Stand desity (stems/ha) & 625 & 313 & 305 \\
Year of land reclamation & 1997 & 1993 & 1986 \\
Year of plantation establishment & 2007 & 2003 & 1996 \\
\hline
\end{tabular}

\subsection{Field Measurements and Sampling}

The heights of all live trees were measured by hypsometers (Cuiyuan, Hangzhou, China) and recorded. Canopy closure is the ratio of the number of steps by the shadows of tree canopies to the total number of steps by the measurer walking along the two diagonal lines of the rectangular plot [47]. Understory biomass was measured in triplicate for each plot by harvesting all aboveground biomass in three randomly allocated $1 \mathrm{~m}^{2}$ areas in the plot in September 2012, and the values in each plot were then averaged prior to the determination of the mean and s.e.m. for each age class.

Five undisturbed soil cores ( $2 \mathrm{~cm}$ diameter) from a depth of $0-10 \mathrm{~cm}$ were randomly collected from each of four sampling points of each plot. Five cores were then mixed homogenously to one composite sample, obtaining four soil samples per plot. Thus, a total of $36(4 \times 9$ plots $)$ soil samples were extracted in June 2012 to determine the stand age effects on WSM and SOC. Because of the strong seasonality of the fine roots [35] and soil microbes [37], we extracted soil samples for fine roots and SMBC in June, August, and October of 2012 using the same soil sampling technique as for WSM.

Litterfall was determined over an entire year. Within each sample plot, two $1 \times 1 \mathrm{~m}$ litter traps, elevated at $1 \mathrm{~m}$ above soil surface to minimize damage from animals, were randomly located to collect litterfall. All litter traps were installed in January 2012, and litter was harvested monthly, from March 2012 to December 2012.

\subsection{Laboratory Analyses}

\subsubsection{Water-Stable Aggregates}

Soil samples for the determination of WSM and SOC were air-dried in the laboratory. Water-stable macroaggregates were collected using $100 \mathrm{~g}$ of air-dried soil, which was placed on a nest of sieves $(\varnothing=23 \mathrm{~cm}$; Jinlisi, Inc., Nanjing, China) with mesh openings that ranged from 0.25 to $2 \mathrm{~mm}$. The sieves were submerged in deionized water and agitated in the Z-axis (at $4 \mathrm{~cm}$ stroke lengths) 525 times over $15 \mathrm{~min}$ using a soil aggregate analyzer (Shunlong, Inc., Shangyu, China). Following the removal of the sieves, soil solution that had passed through the $0.25 \mathrm{~mm}$ screen was poured over a $0.05 \mathrm{~mm}$ screen. Soil passing through the $0.05 \mathrm{~mm}$ screen was allowed to settle for $1 \mathrm{~h}$ and pooled across three depths after decanting, and the sand fractions were removed with forceps. Both the soil and sand fractions were oven-dried $\left(60^{\circ} \mathrm{C}, 48 \mathrm{~h}\right)$ to a constant weight [48]. The small and large macroaggregates were defined as $0.25 \mathrm{~mm} \leq \varnothing<2 \mathrm{~mm}$ and $\varnothing \geq 2 \mathrm{~mm}$ following the method described by Su [49]. The weight percentages of WSM were calculated as

$$
\mathrm{WSM}_{\mathrm{i}}(\%)=\frac{W i}{\text { Total soil weight }}
$$


where WSMi (\%) is the dry weight percentage of soil water-stable macroaggregates for a given diameter class. $W_{i}(i=1,2)$ is the dry weight of aggregates in two size classes (diameters as $0.25-2 \mathrm{~mm}$ and $>2 \mathrm{~mm}$ ) after correction for sand content. Total soil weight was determined by pooling oven-dried weights of all components excluding sands [50].

The mean weight diameter (MWD) of water-stable aggregates was calculated as

$$
\mathrm{MWD}=\sum x i y i
$$

where $y_{i}$ is the proportion of each size class of the total sample and $x_{i}$ the mean diameter of the size class [49].

\subsubsection{SOC}

To determine the organic C content in aggregates and bulk soil, we pooled all samples within each plot into one composite sample for small aggregates, large aggregates, and bulk soil, respectively. The air-dried samples were finely ground and passed through a $0.149 \mathrm{~mm}$ sieve [51], and two grams of the air-dried samples were hydrolyzed with $5 \mathrm{~mL} 1 \mathrm{~mol} \cdot \mathrm{L}^{-1} \mathrm{HCl}$ in a $50 \mathrm{~mL}$ beaker with occasional shaking until any bubbles disappeared in the soil solution, which was then heated at $60{ }^{\circ} \mathrm{C}$ for $2-3 \mathrm{~h}$ to obtain dry samples [51,52]. We subsequently extracted $25 \mu \mathrm{g}$ of the samples to determine the SOC content using an Element Analyzer (Elementar Vario EL, Hanau, Germany). To examine whether the SOC content was higher in WSM than in the bulk soil, we calculated the ratio of the SOC content in WSM to the bulk soil for paired samples within each plot.

\subsubsection{Soil Microbial Biomass Carbon}

To determine the soil microbial biomass carbon (SMBC), fresh soil samples ( $20 \mathrm{~g})$ were filtered through a $2 \mathrm{~mm}$ sieve and fumigated by placing the soil in a vacuum dryer with a vial of soda-lime and a $25 \mathrm{~mL}$ beaker of (alcohol-free) $\mathrm{CHCl}_{3}$. The fumigation-extraction method used was described by Vance et al. [53]. The organic $C$ in soil extracts was measured by TOC-V $\mathrm{CPH}_{\text {TNM-1 }}$ (Shimazu Inc., Kyoto, Japan).

\subsubsection{Litterfall, Fine-Root Biomass, and SMBC}

All harvested litter samples were oven-dried at $70{ }^{\circ} \mathrm{C}$ for $48 \mathrm{~h}$ and then weighed to the nearest $0.01 \mathrm{~g}$. Annual litterfall production was calculated as the sum of litter collected for all sampling dates, scaled to $\mathrm{mg} \cdot \mathrm{ha}^{-1} \cdot \mathrm{year}^{-1}$. The core soil samples for fine-root biomass were soaked in water to separate the roots from the soil, and then hand-sorted to remove visible roots and coarse fragments. The fine roots ( $\varnothing<1 \mathrm{~mm}$, determined using calipers) were selected and further sorted according to their status (live versus dead). Their status was classified in the laboratory using a combination of morphological characteristics, where the live roots were pale-colored on the exterior, elastic and flexible, free of decay, and had a whitish cortex. The dead roots were brown or black, rigid, and inflexible (broke easily), were in various stages of decay, and had a darker cortex [35,54]. When required, a stereomicroscope was used to assist with the differentiation of the root status. Live fine roots were then oven-dried to a constant mass at $70{ }^{\circ} \mathrm{C}$ and weighed [55].

\subsection{Statistical Analysis}

While we used four samples from each sample plot and/or at each sampling date to account for spatial heterogeneity, these samples were not independent. We thus calculated the mean value of these four samples for further statistical analysis. To test our first hypothesis, we employed analysis of variance (ANOVA) to determine the effects of stand age on WSM and SOC. Shapiro-Wilk's tests on model residuals indicated that the assumption of normality was not met at $\alpha=0.05$ for several analyses. To mitigate the violation to the normality assumption, and to improve the coefficient estimates for a small sample size ( $n=3$ for each age class), we bootstrapped the fitted coefficients of all models 
by 1000 iterations using the boot package [56]. To examine the associations between WSM and SOC, we used Pearson's correlation analysis.

To determine the effects of stand age and sampling date on fine-root biomass and SMBC, we used the following model:

$$
Y_{i j k l}=A_{i}+D_{j(k)}+A_{i} \times D_{j(k)}+\pi_{k}+\varepsilon_{l(i j k)}
$$

where $Y_{i j k l}$ is the fine-root biomass or SMBC; $A_{i}(i=1,2,3)$ is the stand age class; $D_{j(k)}(j=1,2,3)$ is the sample date (June, August, and October); $\pi_{k}$ is the random plot effect $(k=1,2, \ldots, 9) ; \varepsilon_{l(i j k)}(1=1,2,3)$ is the sampling error. We conducted the mixed effect analysis using maximum likelihood estimation with the 'Ime4' package [57].

To test our second hypothesis, we initially used simple linear regression to examine the influences of litterfall, fine-root biomass, and SMBC on the quantities of soil aggregates and SOC. We then used multiple regression to examine how soil aggregates and SOC were associated with litterfall, fine-root biomass, and SMBC. However, both the full models and the best models selected by Akaike information criterion indicated strong multicollinearity among predictors (variance inflation factor $>10$ ). We, therefore, employed ridge regression, which was performed using the "ridge" package [58]. In this analysis, we related the WSM and SOC data collected in June 2012 to the fine-root biomass and SMBC data collected separately in June, August, and October, by linear regressions. All analyses were performed with R Statistical Software (version 3.3.1, R Development Core Team, Vienna, Austria) [59].

\section{Results}

The weight percentage of the soil aggregates increased significantly with stand age in both size classes as well as overall (Figure 2, Table 2). The age-associated increase in the weight percentage of aggregates was more pronounced for the small, rather than large aggregates. The quantity of small aggregates was higher than the large aggregates in the nine- and 16-year-old stands (Figure 2). With increasing stand age, the MWD of the soil aggregates was significantly increased (Figure 2, Table 2).

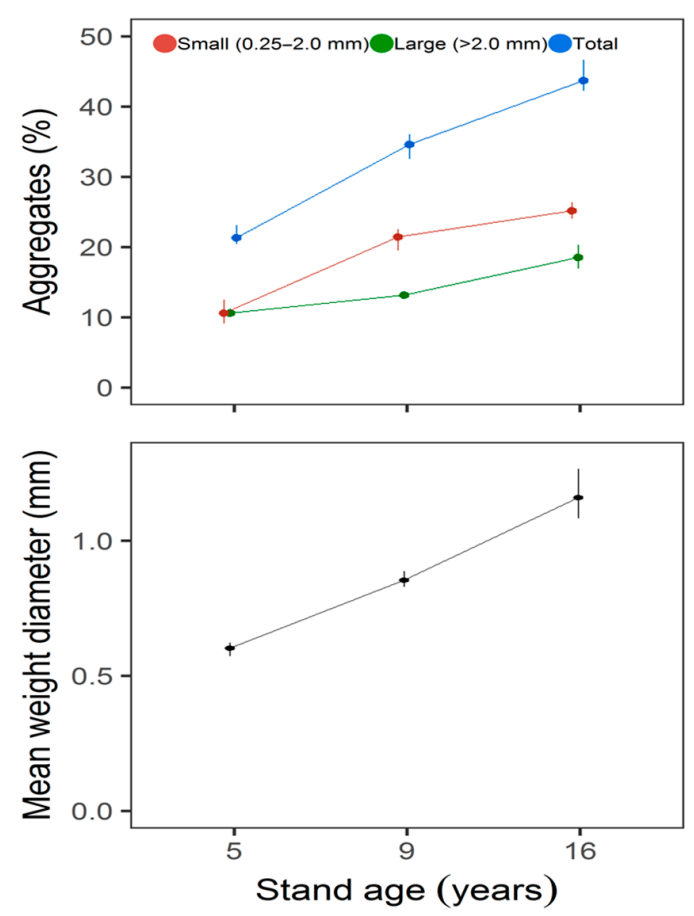

Figure 2. The effects of stand age on the weight percentage and mean weight diameter of soil aggregates in the topsoil $(0-10 \mathrm{~cm})$ of poplar plantations $(n=3)$. Values are bootstrapped means $\pm 95 \%$ confidence intervals (CIs). Differences between stand ages or size classes are significant at $\alpha=0.05$ if their CIs do not overlap the other's mean. 
Table 2. The effects of stand age on small, large, and total aggregates, mean weight diameter, soil organic carbon in bulk soil, and organic carbon content in fine and large aggregates $(n=3)$.

\begin{tabular}{ccccc}
\hline Attribute & Sum of Squares & df & $f$ & $p$ \\
\hline Small aggregates & 1329.8 & 2,6 & 17.61 & $<0.001$ \\
Large aggregates & 374.4 & 2,6 & 19.37 & $<0.001$ \\
Total aggregates & 2962.2 & 2,6 & 23.29 & $<0.001$ \\
Mean weight diameter & 1.7 & 2,6 & 23.92 & $<0.001$ \\
Organic C content in bulk soil & 21.6 & 2,6 & 26.12 & 0.001 \\
Organic C content in fine aggregates & 191.5 & 2,6 & 2.00 & 0.216 \\
Organic C content in large aggregates & 841.6 & 2,6 & 2.02 & 0.213 \\
\hline
\end{tabular}

The soil organic matter content was, on average, significantly different from the bulk soil to small and large aggregates (Figure 3). With stand development, the SOC content of the bulk soil increased with stand age, although the SOC content did not differ significantly between the five- and nine-year-old plantations (Figure 3, Table 2). The SOC content in the small and large aggregates did not change significantly with stand age. Across all stand ages, Pearson's correlation analysis showed that the SOC was positively correlated with the weight percentages of small $(r=0.72, p=0.030)$, large $(r=0.87, p=0.003)$, combined small and large aggregates $(r=0.80, p=0.010)$, and $\operatorname{MWD}(r=0.85$, $p=0.004)$.

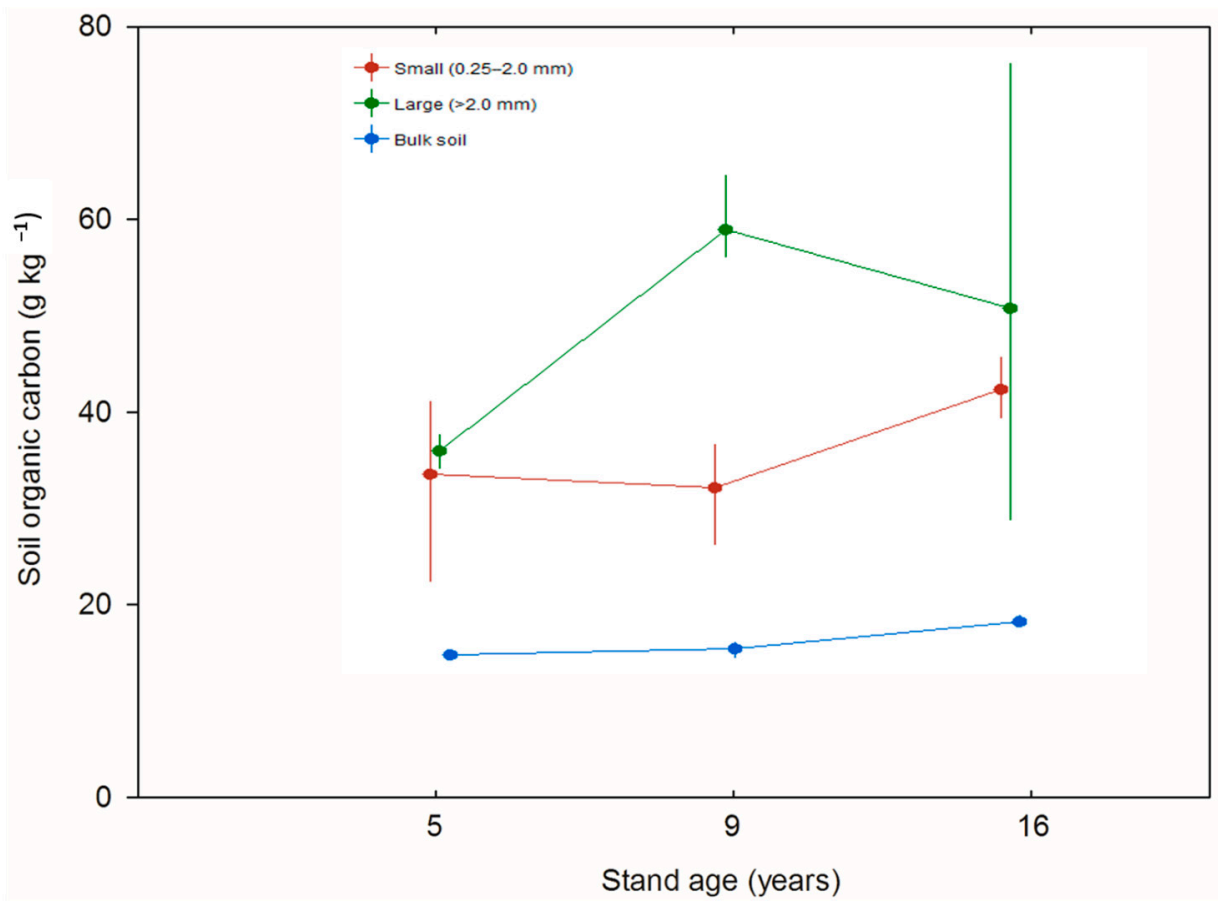

Figure 3. The effects of stand age on soil organic carbon content (SOC) in small and large aggregates $(n=36)$ and bulk soil $(n=12)$. Values are bootstrapped means $\pm 95 \%$ confidence intervals (CIs). Difference is significant at $\alpha=0.05$ if their CIs do not overlap the other's mean.

Litterfall production did not differ with stand age based on analysis of variance (Table 3); however, bootstrapped estimates revealed significantly higher litterfall production in the nine-year over the 16-year-old stands, while it was similar in the five- and 16-year-old stands (Figure 4). The fine-root biomass increased with stand age and differed among sampling dates (Table 3, Figure 4). On average, the fine-root biomass increased with stand age and was higher in June than the other two sampling dates. The SMBC was higher, on average, in the nine-year-old stands, which revealed that the age-related patterns differed with sampling date (Table 3, Figure 4). The microbial biomass carbon 
increased with stand age in June and decreased in October, whereas it was higher in the nine-year-old stands in August (Figure 4).

Table 3. The effects ( $p$ values) of stand age (Age) and sampling date (Date) on litterfall production $\left(\mathrm{mg} \mathrm{ha}^{-1} \cdot \mathrm{year}^{-1}\right)$, fine-root biomass $\left(\mathrm{mg} \cdot \mathrm{ha}^{-1}\right.$ ) and soil microbial biomass carbon (SMBC, $\left.\mathrm{g} \cdot \mathrm{kg}^{-1}\right)$.

\begin{tabular}{lcccc}
\hline Attribute & $\boldsymbol{n}$ & Age & Date & Age $\times$ Date \\
\hline Litterfall & 12 & 0.241 & & \\
Fine-root biomass & 36 & $<0.001$ & $<0.001$ & 0.274 \\
SMBC & 36 & $<0.001$ & $<0.001$ & $<0.001$ \\
\hline
\end{tabular}
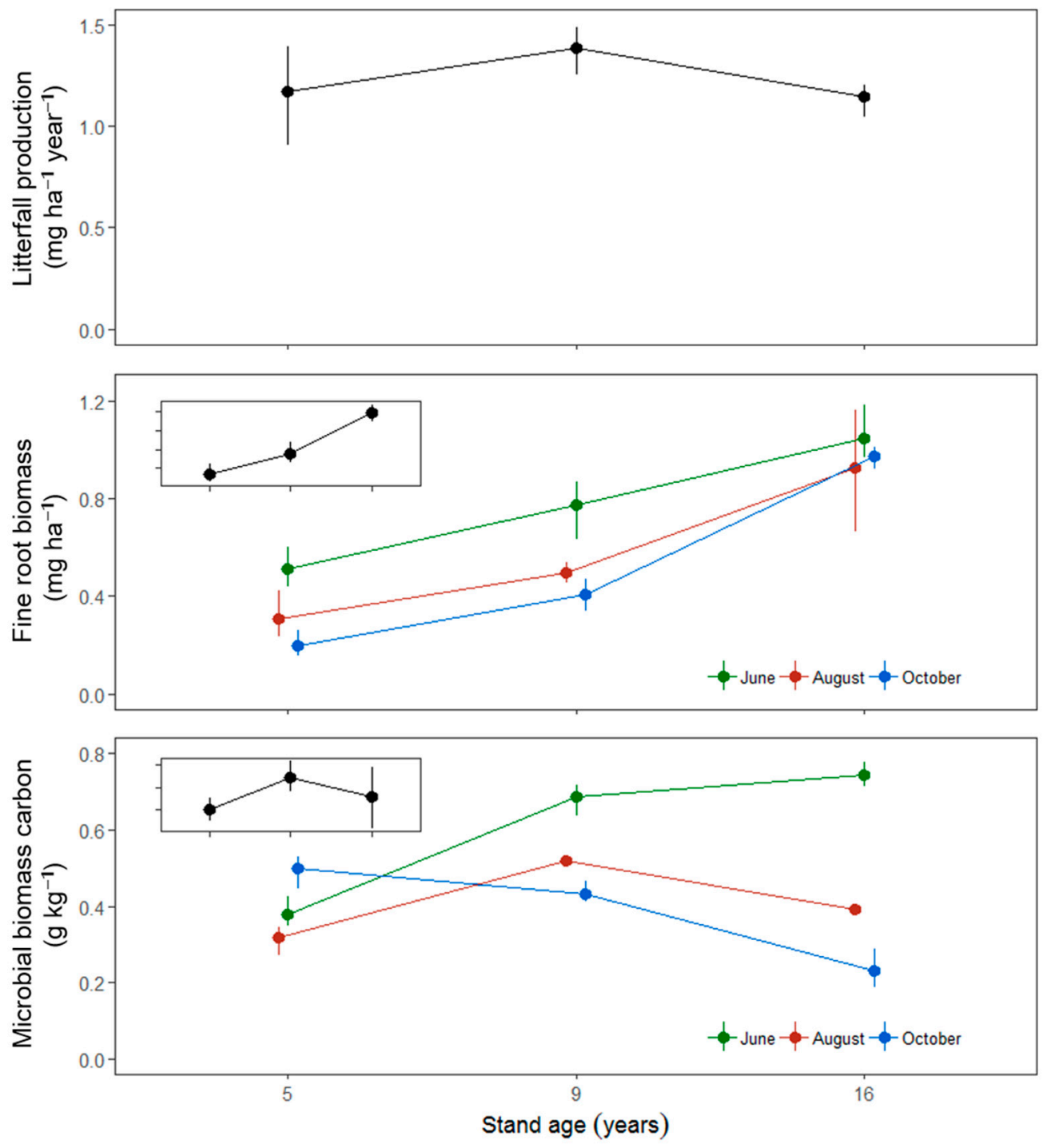

Figure 4. The effect of stand age on annual litterfall production $(n=4)$, fine-root biomass, and soil microbial biomass carbon in the topsoil $(0-10 \mathrm{~cm})$ of poplar plantations $(n=3)$. Inserts are the means for the three sampling dates. Values are bootstrapped means $\pm 95 \%$ confidence intervals (CIs). Differences between stand ages or size classes are significant at $\alpha=0.05$ if their CIs do not overlap the other's mean.

Simple regression analysis showed that the weighted percentages of fine and large aggregates and the SOC in bulk soil increased with fine-root biomass for all sampling dates but was not related to annual litterfall production (Figure 5). The weighted percentages of fine and large aggregates and SOC in bulk soil were all positively associated with the SMBC sampled in June, negatively related to 
the SMBC sampled in October, and insignificantly related to the SMBC sampled in August. Ridge regression indicated that the weighted percentage of fine aggregates was positively affected only by $\mathrm{SMBC}$, and that of the large aggregates increased with both the SMBC and root biomass, while organic $\mathrm{C}$ in the bulk soil increased with fine-root biomass (Table 4).
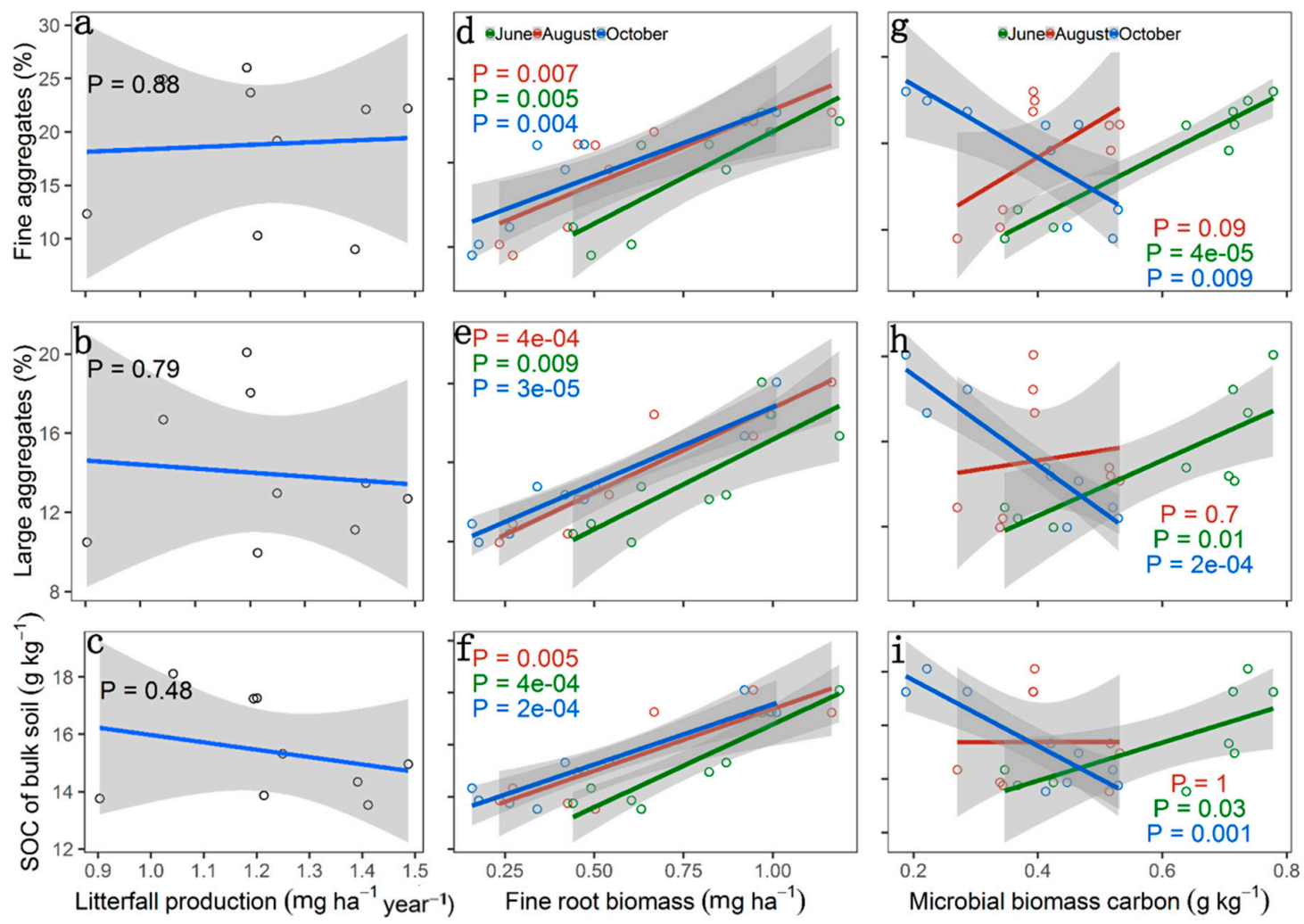

Figure 5. The relationships between soil resident water-stable macroaggregates, soil organic carbon, fine-root biomass, and soil microbial biomass carbon in the topsoil $(0-10 \mathrm{~cm})$ of poplar plantations. Top, middle, and bottom rows are fine aggregates, large aggregates, and SOC of bulk soil in relation to annual litterfall production $(\mathbf{a}, \mathbf{b} \& \mathbf{c})$, fine-root biomass ( $\mathbf{d}, \mathbf{e} \& \mathbf{f})$, and microbial biomass carbon $(\mathbf{g}, \mathbf{h} \& \mathbf{i})$ sampled in June, August, and October, respectively. $R^{2}$ values are $<0.1$ for regressions in $\mathbf{a}, \mathbf{b}$ and $\mathbf{c}$; 0.717 (June), 0.681 (August), and 0.726 (October) for regressions in d; 0.720 (June), 0.871 (August), and 0.926 (October) for regressions in e; 0.864 (June), 0.752 (August), and 0.879 (October) for regressions in f; 0.876 (June), 0.355 (August), and 0.668 (October) for regressions in g; 0.562 (June), 0.014 (August), and 0.848 (October) for regressions in $\mathbf{h} ; 0.442$ (June), 0 (August), and 0.780 (October) for regressions in $\mathbf{i}$. The coefficient of determination and significance of fitted regressions are shown as $p$ values and their corresponding 95\% confidence intervals are shaded.

Table 4. The results of ridge regression, which related annual litterfall production, fine-root biomass, and soil microbial biomass to weighted percentages of fine and large aggregates and soil organic carbon content in bulk soil $(n=3)$.

\begin{tabular}{lccccc}
\hline Predictor & Estimate & Scaled Estimate & Std. Error (Scaled) & $\boldsymbol{t}$ Value (Scaled) & $\operatorname{Pr}(>|t|)$ \\
\hline \multicolumn{4}{l}{ Weighted percentage of fine aggregates } \\
\hline (Intercept) & 0.263 & & & & \\
Root & 3.628 & 2.582 & 2.806 & 0.920 & 0.357 \\
SMBC & 29.631 & 14.485 & 2.820 & 5.136 & $<0.001$ \\
Litterfall & -1.700 & -0.883 & 2.081 & 0.424 & 0.671 \\
\hline
\end{tabular}


Table 4. Cont.

\begin{tabular}{|c|c|c|c|c|c|}
\hline Predictor & Estimate & Scaled Estimate & Std. Error (Scaled) & $t$ Value (Scaled) & $\operatorname{Pr}(>|t|)$ \\
\hline \multicolumn{6}{|c|}{ Weighted percentage of large aggregates } \\
\hline (Intercept) & 7.613 & & & & \\
\hline Root & 5.088 & 3.622 & 1.753 & 2.066 & 0.039 \\
\hline SMBC & 8.269 & 4.042 & 1.753 & 2.306 & 0.021 \\
\hline Litterfall & -2.121 & -1.102 & 1.765 & 0.624 & 0.532 \\
\hline \multicolumn{6}{|c|}{ Organic C content in bulk soil } \\
\hline (Intercept) & 13.047 & & & & \\
\hline Root & 5.319 & 3.786 & 0.797 & 4.751 & $<0.001$ \\
\hline SMBC & 0.559 & 0.273 & 0.800 & 0.341 & 0.733 \\
\hline Litterfall & -1.741 & -0.905 & 0.638 & 1.419 & 0.156 \\
\hline
\end{tabular}

\section{Discussion}

Our results revealed that the quantity of SOC, weight percentages, and MWD of both small and large soil aggregates increased with stand age in poplar plantations that were reclaimed from the ocean via the construction of coastal levees in Eastern China. The enrichment of organic $C$ in both small and large aggregates in contrast to that of the bulk soil was also observed. Further, we found strong positive associations between the weight percentages of both small and large aggregates and fine-root biomass, but not annual litterfall production, whereas the relationships between these and SMBC were strongly dependent on the sampling date of SMBC.

Our results of stand age-associated increases in organic $C$, and the quantity of water-stable aggregates (Figures 2 and 3), were consistent with previous studies [18,60]. However, our analysis indicated that the increase of SOC in differently sized aggregates and bulk soil with stand age resulted primarily from the higher fresh organic matter inputs of fine roots. An analysis of ten primarily stable isotope experiments from the field suggested that $45 \%$ of belowground inputs, on average, were stabilized as SOC, compared with only $8 \%$ for aboveground C inputs through litter [61]. Meanwhile, increased fresh organic $C$ enhances the stability of the aggregates through the binding of mineral particles, which protects the soil against slaking, while reducing aggregate wettability in favor of the formation of stable aggregates [22]. Therefore, stand age-associated increases of weight percentages of small and large aggregates benefitted from increased fine-root biomass.

Stand age-associated trends of soil aggregation in the plantations were expected as fresh organic matter inputs that favored the aggregation of soil particles increased with plantation stand age [2,41]. In our case, the difference of fresh organic matter inputs could not be attributed to the understory litters due to similar understory biomass (Table 1) and aboveground litter biomass (Table 3) among the three age classes. The enrichment of SOC and fine-root biomass with stand development has been reported earlier [62]. Similar phenomenon was also found in afforestation of southeast Spain, that changes of the organic matter input were associated with the rate of accumulation of SOC [63]. The enrichment of SOC and growth of fine-root biomass after afforestation can be attributed to the shift of microbial communities' structure (e.g., increased fungi biomass), rather than SMBC [64]. Temporal increases in large aggregates have previously been attributed to higher fine-root inputs [65-69]. Decomposed fine roots provide $\mathrm{C}$ for the microbial community, which facilitates macroaggregate formation $[2,36,37]$. It was reported that the SOC increased almost $300 \%$ at $0-10 \mathrm{~cm}$ depth following 50 years of afforestation in the Huanglongshan Forest Area, China [18]. This increased SOC was attributed to higher organic matter inputs in tree plantations than in bare land or young soils, due to high net primary production and the prevention of erosion by wind and water from planted trees [70,71]. Several chronosequence studies have reported that fine-root production increases [72] or decreases [73] with stand age. Based on a chronosequence of seven to 201 years since fire, Yuan et al. [54] showed that fine-root biomass peaked in 94-year-old stands, while fine-root production peaked in 11-year-old stands. These results 
indicated that the associations between the SOC and fine roots were dependent on both age spans of chronosequences, and the correlation of fine-root biomass or production, and SOC.

It has been reported that microbial activity contributed to the promotion of SOC in afforested [74] and reforested [75] land, in association with stand age. Furthermore, enhanced microbial biomass preferentially enriched large aggregates [76], which caused the weight percentage of large aggregates to be more closely associated with SMBC, as shown in our results (Table 4). It was reported that more than $50 \%$ of the SMBC content of the total soil [77], and 33\% more soil C [78], were associated with the large aggregates $(\varnothing>2 \mathrm{~mm})$. The $C$ mineralization rate was also higher in the large aggregates in contrast to the small aggregates, due to their relatively higher microbial activities [79]. As the small aggregates served to physicochemically protect organic matter [80] (e.g., fine-root litters or decomposition products of fresh organic fragments), they contained lower levels of available organic matter for microorganisms [81,82]. In addition, as to the different patterns between SMBC and other indexes (SOC, large and small aggregates) in October, compared to other months, it was likely attributable to high seasonal variability [36-38]. A negative relationship between SOC and air temperature was found, while the SMBC exhibited an opposite pattern in autumn, from the results of 12 terrace fields in Southwest China [83]. This might have been the cause of the seasonal differences observed in our results.

\section{Conclusions}

In summary, we found that SOC and MWD increased with stand development following the establishment of a poplar plantation in young coastal soils of Eastern China. Large and small aggregates were associated with fine-root biomass and SMBC. Our analysis indicated that the age-dependent increase in the SOC and aggregates resulted primarily from the higher fresh organic matter inputs of fine roots and microbial biomass. Additionally, the overall soil response, rather than the topsoil specifically, as in this study, warrants further investigation to confirm the finding that the SMBC contributed to aggregate formation.

Author Contributions: Conceptualization, Z.G. and H.Y.H.C.; Formal analysis, Z.G. and S.F.; Data curation, R.Z. and S.P.; Methodology, H.Y.H.C.; Software, H.Y.H.C.; Supervision, H.R.; Writing-original draft, Z.G.; Writing-review and editing, H.Y.H.C.

Funding: This research was funded by [National Key Research and Development Program of China] grant number [2016YFD0600204], [National Natural Science Foundation of China] grant number [41601254] and [Priority Academic Program Development of Jiangsu Higher Education Institutions] (PAPD).

Acknowledgments: We thank the staff of the Forest Farm of Dongtai, Jiangsu Province, China for field assistance, and Ignacie Tumushime at Texas A\&M University for their valuable insights on an earlier version of this paper. We also gratefully thank Lingfeng Mao at Nanjing Forestry University for his constructive comments.

Conflicts of Interest: The authors declare no conflict of interest.

\section{References}

1. Amezketa, E. Soil aggregate stability: A review. J. Sustain. Agric. 1999, 14, 83-151. [CrossRef]

2. Bronick, C.J.; Lal, R. Soil structure and management: A review. Geoderma 2005, 124, 3-22. [CrossRef]

3. Plaza-Bonilla, D.; Cantero-Martínez, C.; Viñas, P.; Álvaro-Fuentes, J. Soil aggregation and organic carbon protection in a no-tillage chronosequence under Mediterranean conditions. Geoderma 2013, 193, 76-82. [CrossRef]

4. Tisdall, J.; Oades, J.M. Organic matter and water-stable aggregates in soils. J. Soil Sci. 1982, 33, 141-163. [CrossRef]

5. Spaccini, R.; Piccolo, A. Effects of field managements for soil organic matter stabilization on water-stable aggregate distribution and aggregate stability in three agricultural soils. J. Geochem. Explor. 2013, 129, 45-51. [CrossRef]

6. Chai, Y.J.; Zeng, X.B.; E, S.Z.; Bai, L.Y.; Su, S.M.; Huang, T. Effects of freeze-thaw on aggregate stability and the organic carbon and nitrogen enrichment ratios in aggregate fractions. Soil Use Manag. 2014, 30, 507-516. [CrossRef] 
7. Chen, C.F.; Liu, W.J.; Jiang, X.J.; Wu, J.E. Effects of rubber-based agroforestry systems on soil aggregation and associated soil organic carbon: Implications for land use. Geoderma 2017, 299, 13-24. [CrossRef]

8. Nzeyimana, I.; Hartemink, A.E.; Ritsema, C.; Stroosnijder, L.; Lwanga, E.H.; Geissen, V. Mulching as a strategy to improve soil properties and reduce soil erodibility in coffee farming systems of Rwanda. Catena 2017, 149, 43-51. [CrossRef]

9. Wang, S.Q.; Li, T.X.; Zheng, Z.C. Distribution of microbial biomass and activity within soil aggregates as affected by tea plantation age. Catena 2017, 153, 1-8. [CrossRef]

10. Zhong, X.L.; Li, J.T.; Li, X.J.; Ye, Y.C.; Liu, S.S.; Hallett, P.D.; Ogden, M.R.; Naveed, M. Physical protection by soil aggregates stabilizes soil organic carbon under simulated $\mathrm{N}$ deposition in a subtropical forest of China. Geoderma 2017, 285, 323-332. [CrossRef]

11. Wu, H.; Guo, Z.; Peng, C. Land use induced changes of organic carbon storage in soils of China. Glob. Chang. Biol. 2003, 9, 305-315. [CrossRef]

12. Meersmans, J.; De Ridder, F.; Canters, F.; De Baets, S.; Van Molle, M. A multiple regression approach to assess the spatial distribution of Soil Organic Carbon (SOC) at the regional scale (Flanders, Belgium). Geoderma 2008, 143, 1-13. [CrossRef]

13. Hajabbasi, M.A.; Jalalian, A.; Karimzadeh, H.R. Deforestation effects on soil physical and chemical properties, Lordegan, Iran. Plant Soil 1997, 190, 301-308. [CrossRef]

14. Zheng, F.L.; He, X.B.; Gao, X.T.; Zhang, C.E.; Tang, K.L. Effects of erosion patterns on nutrient loss following deforestation on the Loess Plateau of China. Agric. Ecosyst. Environ. 2005, 108, 85-97. [CrossRef]

15. Karhu, K.; Wall, A.; Vanhala, P.; Liski, J.; Esala, M.; Regina, K. Effects of afforestation and deforestation on boreal soil carbon stocks - Comparison of measured C stocks with Yasso07 model results. Geoderma 2011, 164, 33-45. [CrossRef]

16. Chen, H.Y.H.; Shrestha, B.M. Stand age, fire and clearcutting affect soil organic carbon and aggregation of mineral soils in boreal forests. Soil Biol. Biochem. 2012, 50, 149-157. [CrossRef]

17. Murty, D.; Kirschbaum, M.U.F.; McMurtrie, R.E.; McGilvray, H. Does conversion of forest to agricultural land change soil carbon and nitrogen? A review of the literature. Glob. Chang. Biol. 2002, 8, 105-123. [CrossRef]

18. Wei, X.; Li, X.; Jia, X.; Shao, M. Accumulation of soil organic carbon in aggregates after afforestation on abandoned farmland. Biol. Fertil. Soil 2013, 49, 637-646. [CrossRef]

19. Blankinship, J.C.; Fonte, S.J.; Six, J.; Schimel, J.P. Plant versus microbial controls on soil aggregate stability in a seasonally dry ecosystem. Geoderma 2016, 272, 39-50. [CrossRef]

20. Denef, K.; Six, J.; Bossuyt, H.; Frey, S.D.; Elliott, E.T.; Merckx, R.; Paustian, K. Influence of dry-wet cycles on the interrelationship between aggregate, particulate organic matter, and microbial community dynamics. Soil Biol. Biochem. 2001, 33, 1599-1611. [CrossRef]

21. Garcia-Franco, N.; Albaladejo, J.; Almagro, M.; Martínez-Mena, M. Beneficial effects of reduced tillage and green manure on soil aggregation and stabilization of organic carbon in a Mediterranean agroecosystem. Soil Tillage Res. 2015, 153, 66-75. [CrossRef]

22. Demenois, J.; Carriconde, F.; Bonaventure, P.; Maeght, J.L.; Stokes, A.; Rey, F. Impact of plant root functional traits and associated mycorrhizas on the aggregate stability of a tropical Ferralsol. Geoderma 2018, 312, 6-16. [CrossRef]

23. Winsome, T.S.; Mccoll, J.G. Changes in chemistry and aggregation of a California forest soil worked by the earthworm Argilophilus papillifer eisen (megascolecidae). Soil Biol. Biochem. 1998, 30, 1677-1687. [CrossRef]

24. Xiang, H.; Zhang, L.; Wen, D. Change of soil carbon fractions and water-stable aggregates in a forest ecosystem succession in South China. Forests 2015, 8, 2703-2718. [CrossRef]

25. Zeglin, L.H.; Stursova, M.; Sinsabaugh, R.L.; Collins, S.L. Microbial responses to nitrogen addition in three contrasting grassland ecosystems. Oecologia 2007, 154, 349-359. [CrossRef] [PubMed]

26. Bardgett, R.D.; Freeman, C.; Ostle, N.J. Microbial contributions to climate change through carbon cycle feedbacks. ISME J. 2008, 2, 805-814. [CrossRef] [PubMed]

27. Zhou, Y.; Pei, Z.; Su, J.; Zhang, J.; Zheng, Y.; Ni, J.; Xiao, C.; Wang, R. Comparing soil organic carbon dynamics in perennial grasses and shrubs in a saline-alkaline arid region, northwestern China. PLoS ONE 2012, 7, e42927. [CrossRef] [PubMed]

28. Lee, S.B.; Lee, C.H.; Jung, K.Y.; Park, K.D.; Lee, D.; Kim, P.J. Changes of soil organic carbon and its fractions in relation to soil physical properties in a long-term fertilized paddy. Soil Tillage Res. 2009, 104, 227-232. [CrossRef] 
29. Linsler, D.; Geisseler, D.; Loges, R.; Taube, F.; Ludwig, B. Temporal dynamics of soil organic matter composition and aggregate distribution in permanent grassland after a single tillage event in a temperate climate. Soil Tillage Res. 2013, 126, 90-99. [CrossRef]

30. Six, J.; Elliott, E.; Paustian, K. Soil macroaggregate turnover and microaggregate formation: A mechanism for C sequestration under no-tillage agriculture. Soil Biol. Biochem. 2000, 32, 2099-2103. [CrossRef]

31. Ussiri, D.; Lal, R.; Jacinthe, P. Soil properties and carbon sequestration of afforested pastures in reclaimed minesoils of Ohio. Soil Sci. Soc. Am. J. 2006, 70, 1797-1806. [CrossRef]

32. Asaye, Z.; Zewdie, S. Fine root dynamics and soil carbon accretion under thinned and un-thinned Cupressus lusitanica stands in, Southern Ethiopia. Plant Soil 2013, 366, 261-271. [CrossRef]

33. Lehmann, A.; Rillig, M.C. Are there temporal trends in root architecture and soil aggregation for Hordeum vulgare breeding lines? Appl. Soil Ecol. 2013, 65, 31-34. [CrossRef]

34. Yuan, Z.Y.; Chen, H.Y.H. Fine root biomass, production, turnover rates, and nutrient contents in boreal forest ecosystems in relation to species, climate, fertility, and stand age: Literature review and meta-analyses. Crit. Rev. Plant Sci. 2010, 29, 204-221. [CrossRef]

35. Brassard, B.W.; Chen, H.Y.H.; Cavard, X.; Laganière, J.; Reich, P.B.; Bergeron, Y.; Paré, D.; Yuan, Z.; Chen, H. Tree species diversity increases fine root productivity through increased soil volume filling. J. Ecol. 2013, 101, 210-219. [CrossRef]

36. Barbhuiya, A.; Arunachalam, A.; Pandey, H.; Khan, M.; Arunachalam, K. Fine root dynamics in undisturbed and disturbed stands of a tropical wet evergreen forest in northeast India. Trop. Ecol. 2012, 53, 69-79.

37. Miller, R.; Jastrow, J. Hierarchy of root and mycorrhizal fungal interactions with soil aggregation. Soil Biol. Biochem. 1990, 22, 579-584. [CrossRef]

38. Ruiz-Peinado, R.; Bravo-Oviedo, A.; López-Senespleda, E.; Montero, G.; Río, M. Do thinnings influence biomass and soil carbon stocks in Mediterranean maritime pinewoods? Eur. J. For. Res. 2012, 132, $253-262$. [CrossRef]

39. Liang, W.; Hu, H.; Liu, F.; Zhang, D. Research advance of biomass and carbon storage of poplar in China. J. For. Res. 2006, 17, 75-79. [CrossRef]

40. Li, Y.; Su, X.; Zhang, B.; Huang, Q.; Zhang, X.; Huang, R. Expression of jasmonic ethylene responsive factor gene in transgenic poplar tree leads to increased salt tolerance. Tree Physiol. 2009, 29, 273-279. [CrossRef] [PubMed]

41. Qiu, S.; Ju, X. Effect of unrestricted nitrogen and irrigation application on soil carbon and nitrogen pools in greenhouse vegetable systems. Better Crops Plant Food 2010, 94, 29-31.

42. National Meteorological Information Center. Annual Data Sets of Meteorological Observation in China. Available online: http:/ / data.cma.cn/ (accessed on 4 May 2010).

43. Johnson, E.A.; Miyanishi, K. Testing the assumptions of chronosequences in succession. Ecol. Lett. 2008, 11, 419-431. [CrossRef] [PubMed]

44. Walker, L.R.; Wardle, D.A.; Bardgett, R.D.; Clarkson, B.D. The use of chronosequences in studies of ecological succession and soil development. J. Ecol. 2010, 98, 725-736. [CrossRef]

45. Cavard, X.; Bergeron, Y.; Chen, H.Y.H.; Pare, D.; Laganiere, J.; Brassard, B. Competition and facilitation between tree species change with stand development. Oikos 2011, 120, 1683-1695. [CrossRef]

46. Gee, G.W.; Bauder, J.W. Particle-Size Analysis-1; Soil Science Society of America, American Society of Agronomy: Madison, WI, USA, 1986; pp. 383-411.

47. Jennings, S.B.; Brown, N.D.; Sheil, D. Assessing forest canopies and understorey illumination: Canopy closure, canopy cover and other measures. Forests 1999, 72, 59-74. [CrossRef]

48. Franzluebbers, A.; Arshad, M. Soil microbial biomass and mineralizable carbon of water-stable aggregates. Soil Sci. Soc. Am. J. 1997, 61, 1090-1097.

49. Su, Y.; Wang, F.; Suo, D.; Zhang, Z.; Du, M. Long-term effect of fertilizer and manure application on soil-carbon sequestration and soil fertility under the wheat-wheat-maize cropping system in northwest China. Nutr. Cycl. Agroecosyst. 2006, 75, 285-295. [CrossRef]

50. Adesodun, J.; Adeyemi, E.; Oyegoke, C. Distribution of nutrient elements within water-stable aggregates of two tropical agro-ecological soils under different land uses. Soil Tillage Res. 2007, 92, 190-197. [CrossRef]

51. Chen, G.S.; Yang, Z.J.; Gao, R.; Xie, J.S.; Guo, J.F.; Huang, Z.Q.; Yang, Y.S. Carbon storage in a chronosequence of Chinese fir plantations in southern China. For. Ecol. Manag. 2013, 300, 68-76. [CrossRef] 
52. Marin, S.; Andrea, L.E.; Ramona, S.L. Assessment of metals bioavailability to vegetables under field conditions using DGT, single extractions and multivariate statistics. Chem. Cent. J. 2012, 6, 119.

53. Vance, E.; Brookes, P.; Jenkinson, D. An extraction method for measuring soil microbial biomass C. Soil Biol. Biochem. 1987, 19, 703-707. [CrossRef]

54. Yuan, Z.Y.; Chen, H.Y.H.; Ostle, N. Fine root dynamics with stand development in the boreal forest. Funct. Ecol. 2012, 26, 991-998. [CrossRef]

55. Beyer, F.; Hertel, D.; Jung, K.; Fender, A.C.; Leuschner, C. Competition effects on fine root survival of Fagus sylvatica and Fraxinus excelsior. For. Ecol. Manag. 2013, 302, 14-22. [CrossRef]

56. Canty, A.; Ripley, B. Package 'Boot'. Available online: http://cran.r-project.org/web/packages/boot/index. html (accessed on 1 March 2017).

57. Bates, D.; Bolker, B.; Walker, S.; Christensen, R.H.B.; Singmann, H.; Dai, B.; Grothendieck, G. Lme4: Linear mixed-effects models using Eigen and S4. R Package Version 2017, 1, 1-13.

58. Moritz, S.; Cule, E. Package 'Ridge': Ridge Regression with Automatic Selection of the Penalty Parameter. Available online: http:/ / github.com/SteffenMoritz/ridge (accessed on 25 March 2017).

59. R Development Core Team. R: A Language and Environment for Statistical Computing, Version 3.3.1; R Foundation for Statistical Computing: Vienna, Austria, 2016.

60. Qiu, L.; Wei, X.; Gao, J.; Zhang, X. Dynamics of soil aggregate-associated organic carbon along an afforestation chronosequence. Plant Soil 2015, 391, 237-251. [CrossRef]

61. Jackson, R.B.; Lajtha, K.; Crow, S.E.; Hugelius, G.; Kramer, M.G.; Piñeiro, G. The Ecology of Soil Carbon: Pools, Vulnerabilities, and Biotic and Abiotic Controls. Annu. Rev. Ecol. Evolut. Syst. 2017, 48, 419-445. [CrossRef]

62. Olupot, G.; Daniel, H.; Lockwood, P.; Mchenry, M.; Mcleod, M.; Gilkes, R.J.; Prakongkep, N. Root contributions to long-term storage of soil organic carbon: Theories, mechanisms and gaps. In Proceedings of the 19th World Congress of Soil Science: Soil Solutions for a Changing World, Brisbane, Australia, 1-6 August 2010; pp. 112-115.

63. Garcia-Franco, N.; Wiesmeier, M.; Goberna, M.; Martínez-Mena, M.; Albaladejo, J. Carbon dynamics after afforestation of semiarid shrublands: Implications of site preparation techniques. For. Ecol. Manag. 2014, 319, 107-115. [CrossRef]

64. Querejeta, J.I.; Roldan, A.; Albaladejo, J.; Castillo, V. The role of mycorrhizae, site preparation, and organic amendment in the afforestation of a semi-arid Mediterranean site with Pinus halepensis. For. Sci. 1998, 44, 203-211.

65. Jastrow, J. Soil aggregate formation and the accrual of particulate and mineral-associated organic matter. Soil Biol. Biochem. 1996, 28, 665-676. [CrossRef]

66. Helfrich, M.; Ludwig, B.; Thoms, C.; Gleixner, G.; Flessa, H. The role of soil fungi and bacteria in plant litter decomposition and macroaggregate formation determined using phospholipid fatty acids. Appl. Soil Ecol. 2015, 96, 261-264. [CrossRef]

67. Gupta, V.V.S.R.; Germida, J.J. Soil aggregation: Influence on microbial biomass and implications for biological processes. Soil Biol. Biochem. 2015, 80, A3-A9. [CrossRef]

68. McNally, S.R.; Laughlin, D.C.; Rutledge, S.; Dodd, M.B.; Six, J.; Schipper, L.A. Root carbon inputs under moderately diverse sward and conventional ryegrass-clover pasture: Implications for soil carbon sequestration. Plant Soil 2015, 392, 289-299. [CrossRef]

69. Mardhiah, U.; Caruso, T.; Gurnell, A.; Rillig, M.C. Just a matter of time: Fungi and roots significantly and rapidly aggregate soil over four decades along the Tagliamento River, NE Italy. Soil Biol. Biochem. 2014, 75, 133-142. [CrossRef]

70. Imhoff, M.L.; Bounoua, L.; Ricketts, T.; Loucks, C.; Harriss, R.; Lawrence, W.T. Global patterns in human consumption of net primary production. Nature 2004, 429, 870-873. [CrossRef] [PubMed]

71. Six, J.; Callewaert, P.; Lenders, S.; De Gryze, S.; Morris, S.; Gregorich, E.; Paul, E.; Paustian, K. Measuring and understanding carbon storage in afforested soils by physical fractionation. Soil Sci. Soc. Am. J. 2002, 66, 1981-1987. [CrossRef]

72. Makkonen, K.; Helmisaari, H.S. Fine root biomass and production in Scots pine stands in relation to stand age. Tree Physiol. 2001, 21, 193-198. [CrossRef] [PubMed] 
73. Chen, L.; Mu, X.; Yuan, Z.; Deng, Q.; Chen, Y.; Yuan, L.Y.; Ryan, L.T.; Kallenbach, R.L. Soil nutrients and water affect the age-related fine root biomass but not production in two plantation forests on the Loess Plateau, China. J. Arid Environ. 2016, 135, 173-180. [CrossRef]

74. Deng, Q.; Cheng, X.; Hui, D.; Zhang, Q.; Li, M.; Zhang, Q. Soil microbial community and its interaction with soil carbon and nitrogen dynamics following afforestation in central China. Sci. Total Environ. 2016, 541, 230-237. [CrossRef] [PubMed]

75. Ma, Z.; Zhang, M.; Xiao, R.; Cui, Y.; Yu, F. Changes in soil microbial biomass and community composition in coastal wetlands affected by restoration projects in a Chinese delta. Geoderma 2017, 289, 124-134. [CrossRef]

76. Gupta, V.V.S.R.; Germida, J.J. Distribution of microbial biomass and its activity in different soil aggregate size classes as affected by cultivation. Soil Biol. Biochem. 1988, 20, 777-786. [CrossRef]

77. Mvan, G.; Merckx, R.; Vlassak, K. Spatial distribution of microbial biomass in microaggregates of a silty-loam soil and the relation with the resistance of microorganisms to soil drying. Soil Biol. Biochem. 1996, 28, 503-510.

78. Handayani, I.P.; Coyne, M.S.; Tokosh, R.S. Soil organic matter fractions and aggregate distribution in response to tall fescue stands. Int. J. Soil Sci. 2010, 5, 1-10. [CrossRef]

79. Manna, M.C.; Swarup, A.; Wanjari, R.H.; Singh, Y.V.; Ghosh, P.K.; Singh, K.N.; Tripathi, A.K.; Saha, M.N. Soil organic matter in a West Bengal Inceptisol after 30 years of multiple cropping and fertilization. Soil Sci. Soc. Am. J. 2006, 70, 121. [CrossRef]

80. Six, J.; Paustian, K.; Elliott, E.T.; Combrink, C. Soil structure and organic matter. Soil Sci. Soc. Am. J. 2000, 64, 681-689. [CrossRef]

81. Wang, Y.; Hu, N.; Ge, T.; Kuzyakov, Y.; Wang, Z.-L.; Li, Z.; Tang, Z.; Chen, Y.; Wu, C.; Lou, Y. Soil aggregation regulates distributions of carbon, microbial community and enzyme activities after 23-year manure amendment. Appl. Soil Ecol. 2017, 111, 65-72.

82. Chen, X.; Li, Z.; Liu, M.; Jiang, C.; Che, Y. Microbial community and functional diversity associated with different aggregate fractions of a paddy soil fertilized with organic manure and/or NPK fertilizer for 20 years. J. Soils Sediment 2015, 15, 292-301. [CrossRef]

83. Piao, H.C.; Liu, G.S.; Wu, Y.Y.; Xu, W.B. Relationships of soil microbial biomass carbon and organic carbon with environmental parameters in mountainous soils of southwest China. Biol. Fertil. Soil 2001, 33, 347-350. [CrossRef]

(C) 2018 by the authors. Licensee MDPI, Basel, Switzerland. This article is an open access article distributed under the terms and conditions of the Creative Commons Attribution (CC BY) license (http://creativecommons.org/licenses/by/4.0/). 